\title{
Pentose Metabolism in Rhizobium leguminosarum MNF300 and in Cowpea Rhizobium NGR234
}

\author{
By M. J. DILWORTH, ${ }^{*}$ R. ARWAS, I. A. MCKAY, S. SAROSO AND \\ A. R. GLEN N \\ Nitrogen Fixation Research Group, School of Environmental and Life Sciences, \\ Murdoch University, Murdoch, Western Australia 6150
}

(Received 22 April 1986)

\begin{abstract}
L-Arabinose is broken down by Rhizobium leguminosarum MNF300 via 2-oxoglutarate semialdehyde. Enzyme activities in cells grown on succinate, mannitol or arabinose indicated much greater modulation of arabinonate dehydratase, 2-keto-3-deoxyarabinonate dehydratase and 2-oxoglutarate semialdehyde dehydrogenase than of arabinose dehydrogenase or of arabinono- $\gamma$-lactonase. In cowpea Rhizobium NGR234, all the enzymes of L-arabinose metabolism except L-arabinono- $\gamma$-lactonase were inducible. Assays for such enzymes in snake bean bacteroids indicated that $L$-arabinose did not reach the bacteroids in large quantities. The Tn5-induced mutant MNF3045 of $R$. leguminosarum was unable to grow on L-arabinose and accumulated L-arabinono- $\gamma$-lactone and L-arabinonate. Product accumulation and enzyme assays suggested that this mutant was defective in $L$-arabinonate dehydratase. It nodulated peas and the nodules fixed $\mathrm{N}_{2}$, indicating that the supply of $\mathrm{L}$-arabinose is not essential for bacteroid function. Another Tn5-induced mutant of $R$. leguminosarum, MNF3041, lacked ribokinase and was unable to grow on D-ribose; this mutant was also able to nodulate peas and fix $\mathrm{N}_{2}$.
\end{abstract}

\section{INTRODUCTION}

Rhizobia can efficiently utilize a variety of pentoses for growth. It is therefore possible that the supply of such compounds by host legumes may be important to nodule formation or function. One approach to the identification of compounds which are important to symbiotic $\mathrm{N}_{2}$ fixation in the legume nodule has been the study of rhizobial mutants blocked in particular steps in catabolism. A mutant of Rhizobium meliloti unable to grow on L-arabinose was identified as defective in the synthesis of 2-oxoglutarate dehydrogenase (Duncan \& Fraenkel, 1979); it continued, however, to degrade L-arabinose at the same rate as the wild-type strain. A similar Tn5-induced mutant also metabolized L-arabinose without growth, and either nodulated later than the wild-type or formed no nodules at all (Duncan, 1981). Mutants of $R$. meliloti which were unable to grow on ribose or on xylose were normal in both nodulation and $\mathrm{N}_{2}$ fixation, and still possessed the capacity to degrade these pentoses (Duncan, 1981). While these data suggest that metabolic intermediates were accumulating, none was identified.

The routes of pentose utilization in rhizobia are not well defined. In Bradyrhizobium japonicum, L-arabinose appears to be degraded to L-2-keto-3-deoxyarabinonate (KDA), which is then cleaved to pyruvate and glycolaldehyde (Fig. 1) via an aldolase reaction (Pedrosa \& Zancan, 1974). While pyruvate and glycolaldehyde were identified as products of 2-keto-3deoxyarabinonate, the alternative route, dehydration to 2-oxoglutarate semialdehyde, was not explored. It was subsequently reported (Duncan, 1979) that $B$. japonicum 61 A76 and cowpea Bradyrhizobium $32 \mathrm{H} 1$ not only possessed KDA aldolase but also 2-oxoglutarate semialdehyde dehydrogenase. The presence of this enzyme suggests that KDA dehydratase may also have

Abbreviation: KDA, 2-keto-3-deoxyarabinonate. 


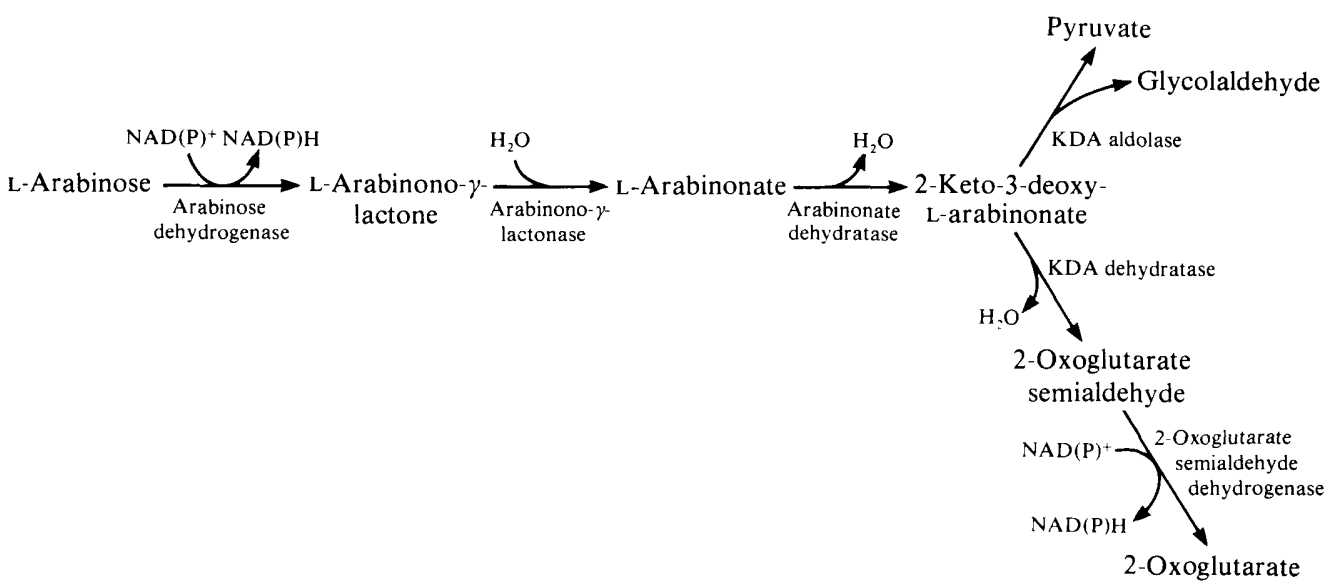

Fig. 1. Pathways of catabolism of L-arabinose in rhizobia.

been present (Fig. 1). In the fast-growing ' $R$. trifolii', ' $R$. phaseoli' [now regarded as biovars trifolii and phaseoli of $R$. leguminosarum], $R$. leguminosarum and $R$. meliloti, KDA aldolase was detectable only in $R$. meliloti, at low activity, while the activities of 2-oxoglutarate semialdehyde dehydrogenase were high in all four organisms. This suggested that dehydration of KDA was the preferred route in these organisms, and that the fast- and slow-growing rhizobia were fundamentally different in their metabolism of L-arabinose (Duncan, 1979). Little information is available concerning the route of D-ribose catabolism in rhizobia. The operation of the pentose phosphate pathway in rhizobia is generally assumed (Stowers, 1985); the likely route of metabolism is phosphorylation to ribose 5-phosphate and isomerization and epimerization to ribulose and xylulose 5-phosphates. The characteristics of a ribose-negative mutant of $R$. meliloti described by Duncan (1981) suggest that this is not the only route since that mutant was defective in ribokinase but still caused ribose disappearance.

We have re-examined the route of L-arabinose catabolism in $R$. leguminosarum MNF300 and in cowpea Rhizobium NGR234 and determined that it follows the 2-oxoglutarate semialdehyde pathway. In addition, we have isolated mutants defective in the metabolism of either D-ribose or $\mathrm{L}$-arabinose and examined their symbiotic properties.

\section{METHODS}

Organisms. Rhizobium leguminosarum MNF300 (strain 300 of Johnston \& Beringer, 1975) is a prototrophic strain which effectively nodulates peas. Mutants derived from this strain are listed in Table 1 . Tn5-induced mutants MNF3041 and MNF3045 were obtained by use of the suicide plasmid pJB4JI as described by Beringer et al. (1978). Strain MNF3400 is a spontaneous mutant which has acquired the ability to grow on arabinonate, and was isolated by plating MNF300 ( $10^{8}$ cells) on minimal salts medium containing L-arabinonate ( $\left.5 \mathrm{mM}\right)$ as sole source of carbon.

Cowpea Rhizobium NGR234, a fast-growing strain nodulating snake bean [Vigna unguiculata subsp. sesquipedalis (L.) Verdc.], was obtained from Dr M. J. Trinick, CSIRO, Canberra, Australia.

Media. Solid media were either Y basal medium (Beringer, 1974) or minimal salts medium (Brown \& Dilworth, 1975), supplemented with single carbon sources at 5 or $10 \mathrm{mM}$. Liquid media contained minimal salts (Brown \& Dilworth, 1975) but with $0.3 \mathrm{mM}$-phosphate, $10 \mathrm{~mm}$-ammonium chloride and $10 \mathrm{~mm}$-carbon source (except for Darabitol, D-ribitol and L-arabinonate, which were at $5 \mathrm{mM}$ ), and were buffered to $\mathrm{pH} 7 \cdot 2$ with $40 \mathrm{mM}-\mathrm{HEPES}$. All strains were grown at $28^{\circ} \mathrm{C}$.

Transduction. Phage RL38 (Buchanan-Wollaston, 1979) was used to demonstrate cotransduction of $\operatorname{Tn} 5$ with the nutritional lesions of $\mathrm{Tn} 5^{+}$mutants as previously described (Arwas et al., 1985). Strain MNF340045 was constructed by RL38-mediated transduction of the Tn5-linked mutation of MNF3045 to MNF3400.

Nodulation assay. Mutants of $R$. leguminosarum were tested for nodulation and $\mathrm{N}_{2}$ fixation $\left(\mathrm{C}_{2} \mathrm{H}_{2}\right.$ reduction) on peas (Pisum sativum cv. Greenfeast). A minimum of 60 single-nodule isolates was recovered from plants which had been inoculated with each mutant, and it was confirmed that the phenotype of these was identical to that of the inoculant strain. 
Table 1. Strains of $R$. leguminosarum and their properties

Growth* on:

Strain Derivation Phenotype $\uparrow \overbrace{\text { D-Ribose L-Arabinose }}^{\begin{array}{c}\text { L-Arabin- D-Ribitol D-Arabitol } \\ \text { onate }\end{array}}$

\begin{tabular}{|c|c|c|c|c|c|c|c|}
\hline MNF300 & Wild-type & & + & + & - & + & + \\
\hline MNF3041\} & Tn $5^{+}$mutants & $\mathrm{Rib}^{-}$ & - & + & ND & + & + \\
\hline MNF3045 $\}$ & of MNF300 & $\mathrm{Ara}^{-}$ & + & - & - & ND & ND \\
\hline MNF3400 & $\begin{array}{l}\text { Spontaneous mutant } \\
\text { of MNF300 }\end{array}$ & Aup $^{+}$ & ND & + & + & ND & ND \\
\hline MNF340045 & $\begin{array}{l}\text { Transductant of } \\
\text { MNF3400 }\end{array}$ & Ara $^{-}$Aup $^{+}$ & ND & - & - & ND & \\
\hline
\end{tabular}

ND, Not done.

${ }^{*}+$, Single colonies visible after $5 \mathrm{~d}$ incubation at $28^{\circ} \mathrm{C} ;-$, no macroscopically visible colonies after $5 \mathrm{~d}$ incubation at $28^{\circ} \mathrm{C}$.

$\dagger$ Phenotypic symbols: Rib, ribose; Ara, arabinose; Aup, arabinonate uptake.

$\ddagger$ MNF340045 was constructed by phage RL38-mediated transduction of the Tn5-linked Ara ${ }^{-}$mutation of MNF3045 to MNF3400.

Nodules containing Rhizobium NGR234 were grown on a dwarf variety of snake bean supplied by Arthur Yates \& Co., Perth, W. Australia, as previously described (Saroso et al., 1984).

Isolation of bacteroids. Bacteroids were isolated from nodules by a modification (McKay et al., 1985) of the Percoll gradient method of Reibach et al. (1981).

Preparation of cell-free extracts. Cells were centrifuged at $6000 \mathrm{~g}$ for $10 \mathrm{~min}$ at $4{ }^{\circ} \mathrm{C}$ and the pellet was washed twice with minimal salts (Brown \& Dilworth, 1975) and resuspended in $20 \mathrm{mM}-\mathrm{HEPES}$ (pH 7.6) containing $1 \mathrm{mM-}$ dithioerythritol. Cell-free extracts were prepared using a French pressure cell as described by McKay et al. (1985).

Uptake assays. Uptake of $\mathrm{D}-\left[{ }^{14} \mathrm{C}\right]$ ribose or $\mathrm{L}-\left[{ }^{14} \mathrm{C}\right]$ arabinonate was measured after cells had been washed twice by centrifugation and resuspended in minimal salts at $28^{\circ} \mathrm{C}$, with unlabelled ribose or arabinonate at $0 \cdot 1 \mathrm{mM}$; the procedure was otherwise that of Hudman \& Glenn (1980).

Radioactive substrates. $\mathrm{D}\left[1^{-14} \mathrm{C}\right] \mathrm{Ribose}\left(58 \mathrm{mCi} \mathrm{mmol}^{-1} ; 2 \cdot 15 \mathrm{GBq} \mathrm{mmol}^{-1}\right)$ was from Amersham, $\mathrm{UK}$, and L[U-14 C]arabinose $\left(210 \mathrm{mCi} \mathrm{mmol}^{-1} ; 7.77 \mathrm{GBq} \mathrm{mmol}^{-1}\right)$ from CEA, France.

L-[U-14 C]Arabinonate $\left(0.77 \mathrm{mCi} \mathrm{mmol}^{-1} ; 28.5 \mathrm{MBq} \mathrm{mmol}^{-1}\right)$ was synthesized as follows. Carrier L-arabinose $\left(3 \mathrm{mg}\right.$ ) and $20 \mu \mathrm{Ci}\left[{ }^{14} \mathrm{C}\right]$ arabinose were dried in vacuo in an Eppendorf tube, and then dissolved in $0.02 \mathrm{ml}$ water at $80^{\circ} \mathrm{C}$. After addition of $0.14 \mathrm{ml}$ of a solution containing $0.114 \mathrm{~g} \mathrm{I}_{2}$ in $1.6 \mathrm{ml}$ methanol, $0.27 \mathrm{ml}$ of a solution containing $1 \mathrm{~g} \mathrm{KOH}$ in $25 \mathrm{ml}$ methanol was added, and the tube was held at $47^{\circ} \mathrm{C}$ for $10 \mathrm{~min}$ and then left at $4{ }^{\circ} \mathrm{C}$ overnight to allow crystallization. The white solid was dissolved in $0.05 \mathrm{ml}$ water, reprecipitated by adding $0.75 \mathrm{ml}$ methanol, and redissolved in $4 \mathrm{ml}$ water for determination of radioactivity and L-arabinonate concentration. Radiochemical purity was established by chromatography on paper using ethyl acetate/pyridine/water, as described below. After development, the chromatograms were cut into $8 \mathrm{~mm}$ strips, and the radioactivity of each strip was counted. All radioactivity coincided with L-arabinonate.

Enzyme assays. All HEPES buffers used were adjusted to the appropriate $\mathrm{pH}$ with $\mathrm{NaOH}$, and all Tris buffers with $\mathrm{HCl}$.

L-Arabinose dehydrogenase (L-arabinose : NADP+ 1-oxidoreductase, EC 1 1 1.1.46) was assayed spectrophotometrically at $340 \mathrm{~nm}$ in a mixture containing (in $1.0 \mathrm{ml}$ final volume) $80 \mu \mathrm{mol}$ Tris buffer (pH 8.5 ), $0.4 \mu \mathrm{mol}$ $\mathrm{NADP}^{+}$and $10 \mu \mathrm{mol} \mathrm{L}$-arabinose. L-Arabinono- $\gamma$-lactonase ( $\mathrm{L}$-arabinono-1,4-lactone lactonohydrolase, EC 3.1.1.15) was measured by incubating (in a $2.0 \mathrm{ml}$ final volume) cell-free extract, $100 \mu \mathrm{mol}$ HEPES buffer

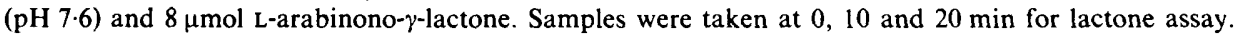

L-Arabinonate dehydratase (L-arabinonate hydro-lyase, EC 4.2.1.25) was assayed by following the disappearance of L-arabinonate from a mixture containing (in a final volume of $2.5 \mathrm{ml}$ ) $5 \mu \mathrm{mol} \mathrm{L}$-arabinonate, $125 \mu \mathrm{mol} \mathrm{HEPES}$ buffer (pH 7.6), $20 \mu \mathrm{mol} \mathrm{MgCl}_{2}$ and $5 \mu \mathrm{mol} 2$-mercaptoethanol. Samples (0.3 ml) withdrawn at 0,15 and $30 \mathrm{~min}$ were heated $\left(5 \mathrm{~min}\right.$ at $\left.100{ }^{\circ} \mathrm{C}\right)$ with $0.03 \mathrm{ml} \mathrm{HCl} / \mathrm{H}_{2} \mathrm{O}(1: 2, \mathrm{v} / \mathrm{v})$ and assayed for lactone content.

KDA dehydratase (2-dehydro-3-deoxy-L-arabinonate hydro-lyase, EC 4.2.1.43) was measured by monitoring the disappearance of KDA from a mixture (in $1.0 \mathrm{ml}$ final volume) containing $100 \mu \mathrm{mol}$ potassium phosphate buffer (pH 7.6), $2 \mu \mathrm{mol} 2$-mercaptoethanol and 1.4 $\mu \mathrm{mol}$ DL-KDA. Samples $(0.02 \mathrm{ml})$ were taken at 0,15 and

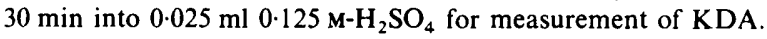

2-Oxoglutarate semialdehyde dehydrogenase (2,5-dioxopentanoate: NADP+ 5-oxidoreductase, EC 1.2.1.26) was measured spectrophotometrically at $340 \mathrm{~nm}$ in a mixture containing (in a final volume of $1.0 \mathrm{ml}$ ) $100 \mu \mathrm{mol}$ potassium phosphate buffer (pH 7.6), $0.4 \mu \mathrm{mol} \mathrm{NADP}+\left(\mathrm{NAD}^{+}\right.$for $R$. leguminosarum MNF300 and MNF3045), $2 \mu \mathrm{mol} \mathrm{KCN}$ and $0.1 \mu \mathrm{mol} 2$-oxoglutarate semialdehyde. 
KDA aldolase (2-dehydro-3-deoxy-L-pentonate glycolaldehyde-lyase, EC 4.1.2.18) was measured by formation of KDA in a mixture containing (in a final volume of $1.0 \mathrm{ml}$ ) $100 \mu \mathrm{mol}$ potassium phosphate buffer (pH 7.6), $10 \mu \mathrm{mol} \mathrm{MgCl}_{2}, 10 \mu \mathrm{mol}$ sodium pyruvate and $10 \mu \mathrm{mol}$ glycolaldehyde. Samples were taken at 0,15 and $30 \mathrm{~min}$ into $0.025 \mathrm{ml} 63 \mathrm{mM}-\mathrm{H}_{2} \mathrm{SO}_{4}$

Ribokinase (ATP:D-ribose 5-phosphotransferase, EC 2.7.1.15) was measured essentially as described by Duncan (1981), except that the final ribose concentration was $10 \mathrm{mM}$ and the buffer was $50 \mathrm{mM}-\mathrm{HEPES}$ (pH 8.2). Ribose-5-phosphate isomerase (D-ribose-5-phosphate ketol-isomerase, EC 5.3.1.6), ribulose-phosphate 3epimerase (D-ribulose-5-phosphate 3-epimerase, EC 5.1.3.1) and transketolase (sedoheptulose-7-phosphate:Dglyceraldehyde-3-phosphate glycolaldehydetransferase, EC 2.2.1.1) were assayed in $50 \mathrm{mM}$-HEPES buffer (pH 7.5) by the methods of Novello \& McLean (1968).

Reagents. Arabinono- $\gamma$-lactone solutions were prepared by heating L-arabinonate in $0 \cdot 1 \mathrm{M}-\mathrm{HCl}\left(5 \mathrm{~min}\right.$ at $\left.100^{\circ} \mathrm{C}\right)$ followed by careful partial neutralization with dilute $\mathrm{NaOH}$ before use. Potassium $\mathrm{L}$-arabinonate and potassium $\mathrm{D}$ ribonate were synthesized from L-arabinose and D-ribose, respectively, by the method of Moore \& Link (1940), DLKDA by the methods of Stoolmiller \& Abeles (1966) and Stoolmiller (1975), and 2-oxoglutarate semialdehyde by the method of Adams (1971). Some 2-oxoglutarate semialdehyde was the generous gift of Dr Y. F. Chang, Department of Microbiology, University of Maryland, USA.

Assay of accumulating compounds in culture filtrates of arabinose mutants. HEPES at the concentrations used in the buffered growth media interfered with arabinono- $\gamma$-lactone or L-arabinonate assays by the method of Hestrin (1949). Accordingly, supernatants of cultures of mutants MNF3045 and 340045 were adjusted to $\mathrm{pH} 5.0$ with $\mathrm{HCl}$, and $20 \mathrm{ml} \mathrm{samples} \mathrm{passed} \mathrm{through} \mathrm{columns}(6 \mathrm{~cm} \times 6 \mathrm{~mm}$ diam. $)$ of Dowex- $50 \mathrm{~W}\left(100-200 \mathrm{mesh}, \mathrm{H}^{+}\right.$form $)$to remove HEPES. Control experiments indicated no losses of arabinono- $\gamma$-lactone or arabinonate in this procedure.

Identification of products from $\mathrm{L}$-arabinose. The products of $\mathrm{L}$-arabinose oxidation by $\mathrm{NADP}^{+}$were analysed after incubation (in a volume of $2.0 \mathrm{ml}$ ) of cell extract ( $3.8 \mathrm{mg}$ protein) with $80 \mu \mathrm{mol}$ Tris buffer (pH 8.5 ), $20 \mu \mathrm{mol} \mathrm{L}$ arabinose, $4 \mu \mathrm{mol} \mathrm{NADP}{ }^{+}$and $1 \mu \mathrm{mol}$ EDTA, and the addition of $330 \mu \mathrm{mol} \mathrm{HCl}$ after $30 \mathrm{~min}$ to stop the reaction. The lactone content was the same whether or not the supernatant was heated with $\mathrm{HCl}$ before analysis. After rotary evaporation to dryness at $30^{\circ} \mathrm{C}$, the mixture was dissolved in $0.2 \mathrm{ml}$ water, treated with $0 \cdot 1 \mathrm{~g}$ moist Dowex$50 \mathrm{~W}$ (100-200 mesh, $\mathrm{H}^{+}$form), centrifuged, and the supernatant used for paper chromatography.

The products from arabinono- $\gamma$-lactone were followed after incubating (in a volume of $2.5 \mathrm{ml}$ ) cell extract ( $3.8 \mathrm{mg}$ protein), $20 \mu \mathrm{mol}$ arabinono- $\gamma$-lactone and $125 \mu \mathrm{mol} \mathrm{HEPES}$. After addition of $330 \mu \mathrm{mol} \mathrm{HCl}$ to halt the reaction, the supernatant was treated with $0 \cdot 1 \mathrm{~g}$ Dowex-50W as above and rotary evaporated at $30{ }^{\circ} \mathrm{C}$ to $0.2 \mathrm{ml}$ and re-centrifuged before chromatography.

L-Arabinonate was incubated in the standard assay system for arabinonate dehydratase for $43 \mathrm{~min}$, then $0.5 \mathrm{ml}$ $25 \mathrm{~mm}$-2,4-dinitrophenylhydrazine in $2 \mathrm{M}-\mathrm{HCl}$ was added. After $20 \mathrm{~min}$ incubation at $30^{\circ} \mathrm{C}$, the mixture was stored frozen before extraction of the 2,4-dinitrophenylhydrazones into ethyl acetate for chromatography.

The products from KDA were generated by incubating (in a final volume of $1.0 \mathrm{ml}$ ) cell extract ( $1 \mathrm{mg}$ protein), $100 \mu \mathrm{mol}$ potassium phosphate (pH 7.6), $2 \mu \mathrm{mol} 2$-mercaptoethanol and $7 \mu \mathrm{mol}$ DL-KDA for $20 \mathrm{~min}$ at $30^{\circ} \mathrm{C}$. To one such incubation was added $5 \mathrm{ml} 5 \mathrm{~mm}$-2,4-dinitrophenylhydrazine in $2 \mathrm{M}-\mathrm{HCl}$, while $2 \mu \mathrm{mol} \mathrm{NAD}{ }^{+}$was added to the other, followed by a further $20 \mathrm{~min}$ incubation at $30^{\circ} \mathrm{C}$ before a similar amount of 2,4dinitrophenylhydrazine was added. Hydrazone formation in both cases was allowed to proceed for $15 \mathrm{~min}$ at $30{ }^{\circ} \mathrm{C}$ and overnight at $4{ }^{\circ} \mathrm{C}$. Dinitrophenylhydrazones were then extracted from the aqueous layers into ethyl acetate for paper chromatography.

Chromatography. All separations were carried out by descending chromatography on Whatman no. 1 paper at 18- $25^{\circ} \mathrm{C}$. 2,4-Dinitrophenylhydrazones of oxo-acids were separated using $1 \%(\mathrm{w} / \mathrm{v})$ aqueous $\mathrm{Na}_{2} \mathrm{CO}_{3}$ (Hockenhull et al., 1953), 0.1 M-glycine buffer (pH 8.5) (Virtanen et al., 1953), butan-1-ol/ethanol/water ( $70: 10: 20$, by vol.; Cavallini et al., 1949) or propan-2-ol/water/ammonia $(200: 20: 10$, by vol.; Smith, 1960). Spots were identified by UV absorbance and by colour reaction with alcoholic $\mathrm{NaOH}$ (Smith, 1960).

L-Arabinose, mannitol, L-arabinono- $\gamma$-lactone, L-arabinonate, KDA and 2-oxoglutarate were separated using propanol/formic acid/water $(6: 3: 1$, by vol.; Weimberg, 1959), ethyl acetate/pyridine/water $(12: 5: 4$, by vol.; Smith, 1960) and butan-2-ol (purified as described by Weimberg, 1959)/formic acid $(95: 5, \mathrm{v} / \mathrm{v})$. All were detectable with alcoholic $\mathrm{AgNO}_{3}$ followed by alcoholic $\mathrm{NaOH}$. Lactones were identified by reagents modified from AbdelAkher \& Smith (1951). Equal volumes of $1 \mathrm{M}-\mathrm{NH}_{2} \mathrm{OH}$. $\mathrm{HCl}$ and $1 \cdot 1 \mathrm{M}-\mathrm{KOH}$ in methanol were mixed, filtered and used as the first dipping solution, followed by $1 \%(\mathrm{w} / \mathrm{v}) \mathrm{FeCl}_{3}$ in methanol containing $3 \mathrm{ml} \mathrm{conc}$. $\mathrm{HCl}$ per $100 \mathrm{ml}$. Sugars were identified with an aniline/diphenylamine $/ \mathrm{H}_{3} \mathrm{PO}_{4}$ reagent (Smith, 1960). Oxo-acids were detected with $0.5 \%(\mathrm{w} / \mathrm{v})$ alcoholic 2,4-dinitrophenylhydrazine, followed by $2 \%(\mathrm{w} / \mathrm{v}) \mathrm{NaOH}$ (Smith, 1960).

Analytical. L-Arabinono- $\gamma$-lactone was determined by the method of Hestrin (1949); L-arabinonate was first converted to the $\gamma$-lactone. DL-KDA was estimated after periodate oxidation for 20 min at $30^{\circ} \mathrm{C}$ under the conditions used by Weissbach \& Hurwitz (1959), or as the semicarbazone (MacGee \& Doudoroff, 1954). 2Oxoglutarate semialdehyde solutions were standardized as the bis-2,4-dinitrophenylhydrazone in methanol at 
$433 \mathrm{~nm}$ (Dagley \& Trudgill, 1965) or as the bis-semicarbazone (MacGee \& Doudoroff, 1954). 2-Oxoglutarate was determined as the 2,4-dinitrophenylhydrazone, using the assay system for pyruvate (Dilworth, 1962).

Both D-ribose and L-arabinose were determined using the orcinol method of Ashwell (1957).

Protein was measured by the Lowry method with bovine serum albumin as the standard.

\section{RESULTS AND DISCUSSION}

\section{Route of L-arabinose metabolism in R. leguminosarum}

The products of L-arabinose oxidation with $\mathrm{NADP}^{+}$in crude extracts of strain MNF300 were identified by chromatography as arabinono- $\gamma$-lactone and arabinonate. The $\gamma$-lactone gave rise to arabinonate on incubation with cell extract, together with small amounts of an oxoacid identified as KDA by its $R_{F}$ and its colour after treatment with alcoholic 2,4dinitrophenylhydrazine followed by alcoholic $\mathrm{NaOH}$. Incubation of L-arabinonate with crude cell extracts produced an oxo-acid identified from its 2,4-dinitrophenylhydrazone as KDA, and smaller amounts of 2-oxoglutarate. Incubation of DL-KDA with cell extract, followed by chromatography of the 2,4-dinitrophenylhydrazones of the products, showed that 2oxoglutarate semialdehyde and lesser amounts of 2-oxoglutarate were produced. No pyruvate or glycolaldehyde derivatives were detected. Addition of $\mathrm{NAD}^{+}$to mixtures after their incubation with DL-KDA resulted in the disappearance of 2-oxoglutarate semialdehyde and the appearance of larger quantities of 2-oxoglutarate.

Cultures of MNF300 metabolizing L-arabinose accumulated 2-oxoglutarate when treated with $1 \mathrm{~mm}$-sodium arsenite to inhibit the 2-oxoglutarate dehydrogenase; the rate of 2oxoglutarate accumulation $\left[4.1 \mu \mathrm{mol} \mathrm{h}^{-1}(\mathrm{mg} \text { dry weight })^{-1}\right]$ equalled the rate of L-arabinose consumption $\left.\left[4.3 \mu \mathrm{mol} \mathrm{h}^{-1} \text { (mg dry weight }\right)^{-1}\right]$. Arabinose-metabolizing cells of cowpea Rhizobium NGR234 also accumulated stoichiometric amounts of 2-oxoglutarate when exposed to $1 \mathrm{mM}$-sodium arsenite (data not shown).

Accordingly, it is suggested that in $R$. leguminosarum MNF300 and in cowpea Rhizobium NGR234 L-arabinose is metabolized via the 2-oxoglutarate semialdehyde pathway rather than via pyruvate and glycolaldehyde produced by KDA aldolase.

\section{Control of L-arabinose pathway}

Activities of the enzymes of the L-arabinose pathway in cells of $R$. leguminosarum MNF300 grown on arabinose, mannitol or succinate (all at $10 \mathrm{mM}$ ) are presented in Table 2 . Synthesis of $\mathrm{L}-$ arabinose dehydrogenase and the lactonase was not tightly controlled; the three later enzymes of the pathway appeared to be more closely regulated and to respond coordinately to growth on mannitol or succinate. The relative activities of the enzymes were consistent with the pattern of products found above; the greater activities of KDA dehydratase and 2-oxoglutarate semialdehyde dehydrogenase restrict KDA accumulation from L-arabinonate. Growth of MNF300 on $10 \mathrm{~mm}$-mannitol plus $10 \mathrm{~mm}$-arabinose did not result in catabolite repression of the arabinose enzymes (Table 2).

KDA aldolase activity as measured was very low; assay of this activity as KDA synthesis is impractical in the face of a relatively active KDA dehydratase. The major indications that the aldolase is unimportant come from the facts that incubation of DL-KDA with cell-free extracts gave rise to neither pyruvate nor glycolaldehyde, and that treatment of arabinose-metabolizing whole cells with arsenite gave rise to 2-oxoglutarate in stoichiometric amounts.

The activities of the enzymes of $\mathrm{L}$-arabinose metabolism in pea bacteroids are also presented in Table 2; arabinose dehydrogenase and arabinono- $\gamma$-lactonase were readily detected, while arabinonate dehydratase, KDA dehydratase and KDA aldolase were at very low activity or absent. 2-Oxoglutarate semialdehyde dehydrogenase activity was present at high levels. The significance of this result is not clear. It suggests either that this enzyme can be regulated independently of the preceding two and may be associated with catabolism of other compounds such as hydroxyproline, glucarate or galactarate (Dagley \& Trudgill, 1965), or that the activity is 


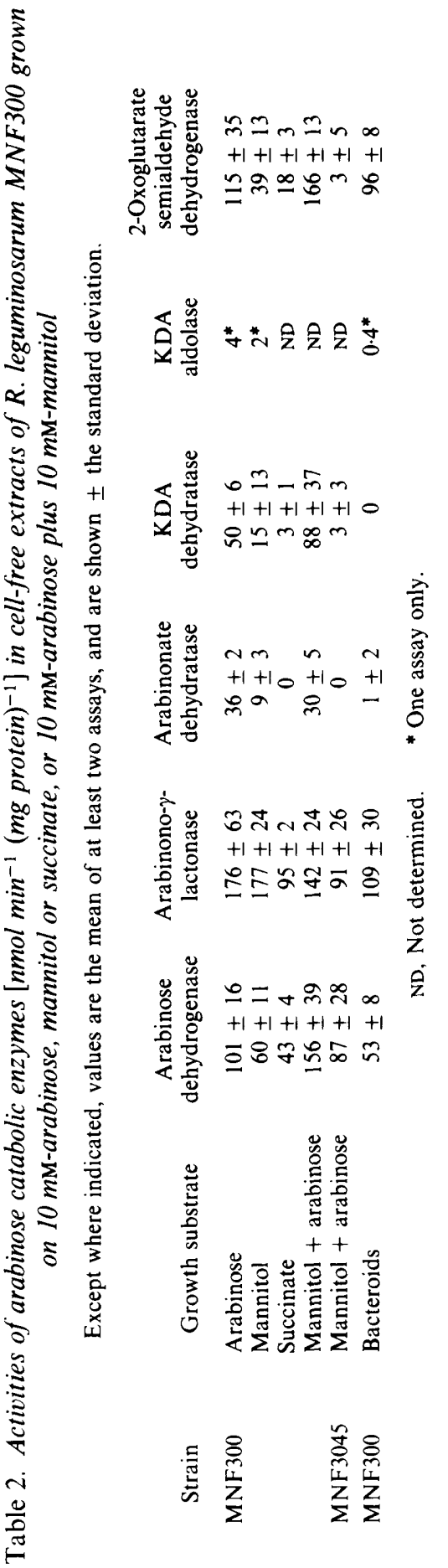


Table 3. Activities of arabinose catabolic enzymes $\left[\mathrm{nmol} \mathrm{min}^{-1}(\mathrm{mg} \text { protein })^{-1}\right]$ in cell-free extracts of cowpea Rhizobium NGR234 grown on $10 \mathrm{mM}$-arabinose, glucose or succinate

Values are the mean of at least two assays, \pm the standard deviation.

$\begin{array}{lcccccc}\begin{array}{l}\text { Growth } \\ \text { substrate }\end{array} & \begin{array}{c}\text { Arabinose } \\ \text { dehydrogenase }\end{array} & \begin{array}{c}\text { Arabinono- } \gamma \text { - } \\ \text { lactonase }\end{array} & \begin{array}{c}\text { Arabinonate } \\ \text { dehydratase }\end{array} & \begin{array}{c}\text { KDA } \\ \text { dehydratase }\end{array} & \begin{array}{c}\text { KDA } \\ \text { aldolase }\end{array} & \begin{array}{c}\text { 2-Oxoglutarate } \\ \text { semialdehyde } \\ \text { dehydrogenase }\end{array} \\ \text { Arabinose } & 95 \pm 17 & 92 \pm 15 & 54 \pm 23 & 36 \pm 4 & 0 \cdot 3 \pm 0 \cdot 1 & 204 \pm 25 \\ \text { Glucose } & 6 \pm 1 & 79 \pm 32 & 0 & 9 \pm 9 & 3 \pm 2 & 18 \pm 53 \\ \text { Succinate } & 10 \pm 4 & 74 \pm 35 & 0 & 17 \pm 8 & 3 \pm 2 & 17 \pm 4 \\ \text { Bacteroids } & 19 \pm 6 & 49 \pm 27 & 2 \pm 3 & 0 & 0 \cdot 5 \pm 0 \cdot 5 & 5 \pm 1\end{array}$

due to a non-specific aldehyde dehydrogenase similar to that recorded by Peterson \& LaRue (1982) for bacteroids of $B$. japonicum.

In cowpea Rhizobium NGR234, arabinose dehydrogenase, arabinonate dehydratase, KDA dehydratase and 2-oxoglutarate semialdehyde dehydrogenase were essentially inducible by arabinose, while only the arabinono- $\gamma$-lactonase was present at significant activities in cells grown on glucose or succinate (Table 3 ). Since snake bean bacteroids show only low activities of arabinose dehydrogenase and no activity for arabinonate dehydratase and KDA dehydratase, it seems unlikely that L-arabinose is supplied to these bacteroids.

Incubation of bacteroids of $R$. leguminosarum MNF300 or of cowpea Rhizobium NGR234 with $\mathrm{L}$-arabinose in the presence of $1 \mathrm{~mm}$-sodium arsenite resulted in only a very slow accumulation of 2-oxoglutarate $\left[1-2 \mathrm{nmol} \mathrm{min}^{-1}(\mathrm{mg} \text { protein })^{-1}\right]$, suggesting that the Larabinose pathway is not operative in either type of bacteroid.

\section{Properties of the Tn5-induced arabinose-negative ( $\left.\mathrm{Ara}^{-}\right)$mutant MNF3045}

MNF3045, derived from MNF300 by Tn5 mutagenesis, was unable to grow on L-arabinose as sole carbon source. Linkage of $\mathrm{Tn} 5$ to the $\mathrm{Ara}^{-}$determinant of this strain was demonstrated by their cotransduction by phage RL38. The Ara- phenotype of MNF3045 reverted to Ara ${ }^{+}$at frequencies of $10^{-6}-10^{-5}$. Revertants of MNF3045 were analysed: each of 20 revertants tested had lost the kanamycin-resistance marker of Tn5. Thus, Tn5 appears to excise precisely at high frequency from its site of insertion in MNF3045. The reversion of Tn5-induced mutations, at high frequency, has not previously been observed in derivatives of $R$. leguminosarum MNF300 (Glenn et al., 1984a,b) and appears to be rare in other bacteria (e.g. Erwinia: Chatterjee et al., 1983). In Escherichia coli, the frequency of precise excision of $\operatorname{Tn} 5$ is known to be dependent on the site of insertion; frequencies as high as $10^{-6}-10^{-5}$ have been found only at certain sites in $\mathrm{F}^{\prime}:$ :Tn5 plasmids (Berg et al., 1983; Egner \& Berg, 1981).

\section{Arabinose catabolic enzymes in Ara- mutants}

Activities of arabinose catabolic enzymes in extracts from MNF3045 grown on $10 \mathrm{~mm}$ mannitol plus $10 \mathrm{mM}$-L-arabinose are compared with those for MNF300 grown on the same substrates in Table 2. The levels of arabinose dehydrogenase and arabinono- $\gamma$-lactonase were similar to those found in extracts of arabinose-grown MNF300. MNF3045 did not produce measurable levels of arabinonate dehydratase; the levels of KDA dehydratase and 2oxoglutarate semialdehyde dehydrogenase were also low. The data strongly suggest that the last three enzymes of the pathway are regulated quite independently of the first two. Whether the mutation of MNF3045 occurs in a control gene or as a polar mutation in a polycistronic operon remains to be determined.

MNF3400 is a spontaneous mutant of MNF300 which has gained the ability to transport L-

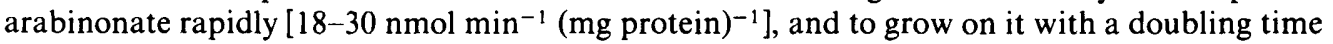
of $3 \cdot 3 \mathrm{~h}$. By contrast, MNF300 transported L-arabinonate at $2-3 \mathrm{nmol} \mathrm{min}^{-1}(\mathrm{mg} \text { protein })^{-1}$ and failed to grow on it.

When the mutation in MNF3045 was transduced into MNF3400, the resulting strain (MNF340045) was unable to grow on either L-arabinose or L-arabinonate. Since cells of 
Table 4. Concentrations of compounds in culture supernatants of MNF3045 and MNF340045 grown on $10 \mathrm{mM}$-mannitol plus $10 \mathrm{mM}$-L-arabinose

\begin{tabular}{|c|c|c|c|}
\hline \multirow[b]{2}{*}{ Mutant } & \multicolumn{2}{|c|}{ Concn (mM) of: } & \multirow{2}{*}{$\begin{array}{c}\text { Change in } \\
\text { arabinose } \\
\text { concn } \\
(\mathrm{mM})\end{array}$} \\
\hline & $\begin{array}{l}\text { Arabinono- } \gamma- \\
\text { lactone }\end{array}$ & Arabinonate & \\
\hline MN3045 & $2 \cdot 0$ & $4 \cdot 0$ & $6 \cdot 2$ \\
\hline MNF340045 & $0 \cdot 3$ & $3 \cdot 5$ & $3 \cdot 5$ \\
\hline
\end{tabular}

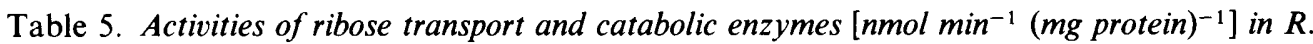
leguminosarum strains MNF300 and MNF3041 grown on $10 \mathrm{mM}$-glucose plus $10 \mathrm{mM}$-ribose

\begin{tabular}{|c|c|c|c|c|c|}
\hline Strain & $\begin{array}{c}\text { Ribose } \\
\text { transport } \\
\text { rate }\end{array}$ & Ribokinase & $\begin{array}{l}\text { Ribose-5- } \\
\text { phosphate } \\
\text { isomerase }\end{array}$ & $\begin{array}{l}\text { Ribulose- } \\
\text { 5-phosphate } \\
\text { epimerase }\end{array}$ & Transketolase \\
\hline $\begin{array}{l}\text { MNF300 } \\
\text { MNF3041 }\end{array}$ & $\begin{array}{l}16 \pm 8 \\
18 \pm 2\end{array}$ & $18 \pm 1$ & $\begin{array}{l}35 \pm 6 \\
35 \pm 15\end{array}$ & $\begin{array}{l}64 \pm 20 \\
87 \pm 4\end{array}$ & $\begin{array}{l}68 \pm 14 \\
44 \pm 11\end{array}$ \\
\hline
\end{tabular}

MNF3400 can take up and grow on L-arabinonate, these results confirm that the lesion in MNF3045 must block arabinose catabolism at a step subsequent to L-arabinonate.

Accumulating compounds in cultures of MNF3045 and MNF340045

Mutants of $R$. meliloti unable to grow on L-arabinose can nevertheless metabolize it (Duncan, 1981 ). When $R$. leguminosarum MNF3045 or MNF340045 was grown on 10 mM-mannitol plus $10 \mathrm{mM}$-L-arabinose for $24 \mathrm{~h}$, much of the L-arabinose disappeared (Table 4). The supernatant contained a compound reactive with alkaline hydroxylamine and another compound which could be converted to a reactive one by treatment in $0.2 \mathrm{M}-\mathrm{HCl}$ for $5 \mathrm{~min}$ at $100{ }^{\circ} \mathrm{C}$. Chromatography of the material from MNF3045 in the ethyl acetate/pyridine/water solvent, which resolved mannitol, $\mathrm{L}$-arabinose, $\mathrm{L}$-arabinonate and $\mathrm{L}$-arabinono- $\gamma$-lactone, showed that all four compounds were present in the culture filtrate. Cultures of MNF300 grown under similar conditions did not accumulate either L-arabinonate or L-arabinono- $\gamma$-lactone but a low concentration of 2-oxoglutarate $(0.25 \mathrm{~mm})$ was detected.

The amounts of L-arabinose metabolized by mutants MNF3045 and MNF340045 corresponded to the total of L-arabinonate plus L-arabinono- $\gamma$-lactone accumulated in the medium (Table 4). The excretion of $L$-arabinonate and L-arabinono- $\gamma$-lactone indicates that $L$ arabinonate cannot be further metabolized.

The mutant of $R$. meliloti described by Duncan (1981) as being able to metabolize L-arabinose but not to grow on it may well behave like $R$. leguminosarum MNF3045 and MNF340045 and accumulate intermediates in a similar way.

\section{Properties of the ribose-negative (Rib-) mutant MNF3041}

Mutant MNF3041 was unable to grow on ribose as sole source of carbon. When incubated in 5 mM-ribose following growth on $5 \mathrm{~mm}$-glucose plus $5 \mathrm{~mm}$-ribose, it degraded ribose at a rate of $0.54 \mu \mathrm{mol} \mathrm{h}^{-1}$ (mg dry weight $)^{-1}$; MNF300 under similar conditions grew with a generation time of $6.7 \mathrm{~h}$ and catabolized ribose at a rate of $2.02 \mu \mathrm{mol} \mathrm{h}^{-1}(\mathrm{mg} \text { dry weight })^{-1}$. The consumption of ribose by MNF3041 also resulted in incorporation of radioactivity from $\left[{ }^{14} \mathrm{C}\right]$ ribose into ethanol-insoluble cell material (data not shown); some $74 \%$ of the total radioactivity taken up was found in the insoluble fraction. Thus, MNF3041 appears to be similar in phenotype to the $\mathrm{Rib}^{-}$mutant $M D 5$ of $R$. meliloti (Duncan, 1981) in its failure to grow on ribose but its ability to utilize it.

The lesion in MNF3041 appears most likely to be an inability to produce ribokinase, since cells of MNF3041 take up ribose at rates at least as high as those for MNF300 (Table 5) and 
other early enzymes of ribose catabolism via the oxidative pentose phosphate pathway are present in extracts of MNF3041 grown on glucose plus ribose. This conclusion is consistent with the ability of MNF3041 to grow on D-ribitol (a precursor of D-ribulose) or D-arabitol (a precursor of D-xylulose).

As with other mutants of $R$. leguminosarum which cannot use $\mathrm{C}_{6}$ or $\mathrm{C}_{12}$ sugars for growth (Glenn et al., 1984a,b) and with mutants of $R$. meliloti unable to use pentoses, mutants of $R$. leguminosarum unable to use L-arabinose or D-ribose are still able to form nodules and to fix $\mathrm{N}_{2}$ normally. No absolute requirement for large exogenous supplies of either of these compounds can therefore be necessary for nodule formation or function.

\section{REFERENCES}

AbDel-AKHER, M. \& SMITH, F. (1951). The detection of carbohydrate esters and lactones after separation by paper chromatography. Journal of the American Chemical Society 73, 5859-5860.

ADAMS, E. (1971). Enzymes and intermediates of hydroxyproline degradation. Methods in Enzymology 17B, 266-306.

Arwas, R., McKay, I. A., Rowney, P., Dilworth, M. J. \& GlenN, A. R. (1985). Properties of organic acid utilization mutants of Rhizobium leguminosarum strain 300. Journal of General Microbiology 131, 2059-2066.

Ashwell, G. (1957). Colorimetric analysis of sugars. Methods in Enzymology 3, 73-105.

Berg, D. E., Egner, C. \& Lowe, J. B. (1983). Mechanism of F-factor enhanced excision of transposon Tn5. Gene 22, 1-7.

BERINGER, J. E. (1974). R factor transfer in Rhizobium leguminosarum. Journal of General Microbiology 84, 188-198.

Beringer, J. E., Beynon, J. L., Buchanan-WollasTON, A. V. \& JoHNSTON, A. W. B. (1978). Transfer of the drug-resistance transposon $\operatorname{Tn} 5$ to Rhizobium. Nature, London 276, 633-634.

Brown, C. M. \& Dilworth, M. J. (1975). Ammonia assimilation by Rhizobium cultures and bacteroids. Journal of General Microbiology 86, 39-48.

Buchanan-Wollaston, A. V. (1979). Generalized transduction in Rhizobium leguminosarum. Journal of General Microbiology 112, 135-142.

Cavallini, D., Frontali, N. \& Toschi, G. (1949). Determination of keto-acids by partition chromatography on filter paper. Nature, London 163, 568-569.

Chatterjee, A. K., Thurn, K. K. \& Feese, D. A. (1983). Tn 5 induced mutations in the enterobacterial phytopathogen Erwinia chrysanthemi. Applied and Environmental Microbiology 45, 644-650.

Dagley, S. \& Trudgill, P. W. (1965). The metabolism of galactarate, D-glucarate and various pentoses by species of Pseudomonas. Biochemical Journal 95, 48-58.

DilworTh, M. J. (1962). Oxygen inhibition in Azotobacter vinelandii. Pyruvate oxidation. Biochimica et biophysica acta 56, 127-138.

DunCAN, M. J. (1979). L-Arabinose metabolism in rhizobia. Journal of General Microbiology 113, 177179.

Duncan, M. J. (1981). Properties of Tn5-induced carbohydrate mutants in Rhizobium meliloti. Journal of General Microbiology 122, 61-67.

Duncan, M. J. \& Fraenkel, D. G. (1979). $\alpha-$
Ketoglutarate dehydrogenase mutant of Rhizobium meliloti. Journal of Bacteriology 137, 415-419.

EGNER, C. \& BERG, D. E. (1981). Excision of transposon $\operatorname{Tn} 5$ is dependent on the inverted repeats but not on the transposase function of $\operatorname{Tn} 5$. Proceedings of the National Academy of Sciences of the United States of America 78, 459-463.

Glenn, A. R., Arwas, R., McKay, I. A. \& DilWORTH, M. J. (1984a). Fructose metabolism in wildtype, fructokinase-negative and revertant strains of Rhizobium leguminosarum. Journal of General Microbiology 130, 231-237.

GlenN, A. R., McKay, I. A., ARwas, R. \& DilWORTH, M. J. (1984b). Sugar metabolism and the symbiotic properties of carbohydrate mutants of Rhizobium leguminosarum. Journal of General Microbiology 130, 239-245.

HESTRIN, S. (1949). The reaction of acetylcholine and other carboxylic acid derivatives with hydroxylamine, and its analytical application. Journal of Biological Chemistry 180, 249-261.

Hockenhull, D. J. D., Hunter, G. D. \& Herbert, M. W. (1953). Separation of $\alpha$-keto acids by paper chromatography. Chemistry and Industry, 127.

Hudman, J. F. \& GlenN, A. R. (1980). Glucose uptake by free-living and bacteroid forms of Rhizobium leguminosarum. Archives of Microbiology 128, 7277.

Johnston, A. W. B. \& BERINGER, J. E. (1975). Identification of the Rhizobium strains in pea root nodules using genetic markers. Journal of General Microbiology 87, 343-350.

MacGee, J. \& Doudoroff, M. (1954). A new phosphorylated intermediate in glucose oxidation. Journal of Biological Chemistry 210, 617-626.

MCKay, I. A., GlenN, A. R. \& Dilworth, M. J. (1985). Gluconeogenesis in Rhizobium leguminosarum MNF3841. Journal of General Microbiology 131, 2067-2073.

MOORE, S. \& LINK, K. P. (1940). Carbohydrate characterization. I. The oxidation of aldoses by hypoiodite in methanol. II. The identification of seven aldomonosaccharides as benzimidazole derivatives. Journal of Biological Chemistry 133, 293311.

Novello, F. \& Mclean, G. (1968). The pentose phosphate pathway of glucose metabolism. Biochemical Journal 107, 775-791.

Pedrosa, F. O. \& ZanCAN, G. T. (1974). L-Arabinose metabolism in Rhizobium japonicum. Journal of Bacteriology 119, 336-338. 
Peterson, J. B. \& LaRue, T. A. (1982). Soluble aldehyde dehydrogenase and metabolism of aldehydes by soybean bacteroids. Journal of Bacteriology 151, 1473-1484.

Reibach, P. H., Mask, P. L. \& Streeter, J. (1981). A rapid one-step method for the isolation of bacteroids from root nodules of soybean plants, utilizing selfgenerating Percoll gradients. Canadian Journal of Microbiology 27, 491-495.

Saroso, S., Glenn, A. R. \& Dilworth, M. J. (1984). Carbon utilization by free-living and bacteroid forms of cowpea Rhizobium NGR234. Journal of General Microbiology 130, 1809-1814.

Stoolmiller, A. C. (1975). DL- and L-2-keto-3deoxyarabonate. Methods in Enzymology 41B, 101 103.

Stoolmiller, A. C. \& Abeles, R. H. (1966). Formation of $\alpha$-ketoglutaric semialdehyde from L-2-keto-3deoxyarabonic acid and isolation of L-2-keto-3- deoxyarabonate dehydratase from Pseudomonas saccharophila. Journal of Biological Chemistry 241, 5764-5771.

SMITH, I. (1960). Chromatographic Techniques. London: Heinemann.

STOWERS, M. D. (1985). Carbon metabolism in Rhizobium species. Annual Review of Microbiology 39 , 89-108.

Virtanen, A. I., Miettinen, J. K. \& Kunttu, H. (1953). $\alpha$-Ketoacids in green plants. Acta chemica scandinavica 7, 38-44.

WEIMBERG, R. (1959), L-2-Keto-4,5-dihydroxyvaleric acid : an intermediate in the oxidation of $\mathrm{L}$-arabinose by Pseudomonas saccharophila. Journal of Biological Chemistry 234, 727-732.

Weissbach, A. \& Hurwitz, J. (1959). The formation of 2-keto-3-deoxyheptonic acid in extracts of Escherichia coli. Journal of Biological Chemistry 234, 705709 . 